\title{
Assessment of Knowledge Attitude and Perception of People Living with HIV Regarding Tuberculosis Infection and Control in Agege, Lagos State
}

\author{
Article by Dada Julianah Imoleayo ${ }^{1}$, Abiodun Olaiya Paul ${ }^{2}$ \\ Texila American University Guyana \\ E-mail: Julianahdada2@gmail.com
}

\begin{abstract}
Background: About one-third of the world's population are infected with latent TB, which implies that these people have been infected but not yet ill and cannot spread the disease (WHO, 2016). Those infected with TB have 10\% lifetime risk of falling ill, while immunosuppressed states such as people living with HIV(PLHIVs) and other immunosuppressive conditions have higher risks of falling ill (WHO, 2016). Therefore, this study aimed to assess the level of knowledge, attitudes and perception of PLHIVs regarding Tuberculosis infection and control in Agege local government area, Lagos.

Methodology: A quantitative research using descriptive cross- sectional design and simple random sampling technique was utilized to administer a structured questionnaire which was used for data collection. The data collected was analyzed using SPSS version 20

Results: Many of the respondents (71.9\%) were aware of TB but only 35.7\% demonstrated good knowledge of TB infection prevention and control in their response. Females had higher overall fair knowledge with 75 (60.9\%) females out of 123 and only 48(39\%) males out of 123 having over all fair knowledge of TB infection control. Also, there was statistically significant association between gender and knowledge of respondents about TB.

Discussion and conclusion: Findings from this study revealed that despite a relatively fair perception and attitude towards TB infection control by people living with HIV, there was poor knowledge about $T B$ infection prevention and control. This showed poor understanding of the information given, therefore there is need to give adequate detailed information about TB to all PLHIV.
\end{abstract}

Keywords: Tuberculosis, HIV/AIDS, co-infection, Knowledge, Attitude, Perception.

\section{Introduction}

There are several opportunistic infections of Human Immunodeficiency Virus (HIV) but Tuberculosis (TB) remains the leading cause of death among people living with HIV (PLHIV) despite several awareness campaigns on Tuberculosis and HIV by several local and international organizations. HIV increases the chances of TB infection among PLWHA. (1), 2008). TB is very infectious and its causative organism is spread from person to another through inhalation when an infected person coughs, sneezes or spits out saliva (2).

About one-third of the world's population are infected with latent TB, which implies that these people have been infected by TB bacteria however are not yet ill with TB disease and cannot spread the disease (WHO, 2016). Those infected with TB bacteria have 10\% lifetime risk of falling ill with TB while individuals with compromised immune systems, such as people living with HIV, malnourished or people with diabetes, and drug users have been found to have higher risks of falling ill. HIV on the other hand remains a major global public health issue, having claimed several lives. The Human Immunodeficiency Virus (HIV) focusses on the immune system and weakens the defense systems of the infected persons against infections and some types of cancer. (3).

UNAIDs 2016 global statistics fact sheet on HIV reported that 36.7 million people globally were living with HIV. Although 78 million people have become infected with HIV since the start of the epidemic, 35 million people have died from AIDS-related illnesses since the start of the epidemic. Tuberculosis-related deaths among people living with HIV have fallen by 32\% since 2004 but Tuberculosis remains the leading cause of death among people living with HIV, accounting for around one in three AIDS-related deaths. As at 2015, the HIV prevalence rate in Nigeria is estimated to be $3.1 \%$. 
While TB/HIV co-infection is not regarded as a major problem in developed countries such as Australia because only about $11 \mathrm{~TB} / \mathrm{HIV}$ co- infected clients were identified in 2006, countries in sub Saharan Africa have as high as $50-70 \%$ co-infection rate (4)

The United Nations in 2001 declared HIV/AIDS a global emergency which is of devastating impact and stated that morbidity and mortality relating to TB/HIV were expected to increase significantly in future (5). The challenge is further compounded by the fact that TB is a leading cause of morbidity and mortality among people living with HIV (6)

TB and HIV are entwined, fuel each other and together make up a leading cause of mortality globally (7). It is estimated that mortality rates among TB patients co-infected with HIV are 3 to 4 times higher than among those who are not HIV infected. Co-infection accounts for about 30-40\% of deaths among those who are infected with HIV (8). TB and HIV are dual epidemics and have stimulated the need for collaboration in the implementation of TB/HIV programmes to ensure reduction in the burden of $\mathrm{TB}$ among people living with HIV as well as reducing the burden of HIV among TB infected people.

\section{Methods}

\section{Study design and area}

The study was a descriptive cross-sectional design which was conducted among people living with HIV and who were currently enrolled into care including clients. Such clients included those who were both on ART and pre-ART in one of the HIV treatment facilities in Lagos state, Nigeria. The study was carried out in a high-volume HIV comprehensive care and treatment centre in Agege Local Government Area (LGA). The facility also provides care and treatment for all categories of susceptible TB cases. Sango PHC is a Public Primary health facility that was activated to offer comprehensive HIV care and treatment in Agege Local Government Area. The land mass of Agege LGA is $17 \mathrm{~km}$ square with an estimated population of 461,743 people according the 2006 census.

\section{Sample size and sampling procedure}

Sample size was calculated using Kish Leslie formula for cross sectional studies (with sample size N generated with formula $\mathrm{N}=\mathrm{pqz}^{2} / \mathrm{d}^{2}$. Prevalence of $34 \%$ was derived from the nationwide study report on the HIV and TB project supported by the Global fund in 2012 (9). q is 1-p and $\mathrm{z}$ is 1.96 (for 5\% alpha error, C.I of 95\%); and d is precision which is 0.05 . Which gave the sample size of 345 participants. Simple random sampling technique was adopted in this study to select the respondents. Respondent were randomly selected among HIV positive clients who were enrolled to access care at Sango PHC and had never been diagnosed with TB or commenced on TB treatment. The researcher and four trained research assistants collected data for the survey. The researcher with the four assistants administered the questionnaires to people living with HIV at the selected health facility. The research assistants were trained to ensure that they had enough understanding of the questionnaire prior to the commencement of data collection. The training of research assistance was directed at the objectives of the study, the sampling process, how to obtain informed consent from respondents, and basic interviewing skills needed to obtain information from respondents.

\section{Inclusion criteria}

Respondents who participated in the study were clients who were HIV positive; are enrolled to access care in the selected PHC; had either started ART or were yet to commence ART and had never been diagnosed with TB or commenced on TB treatment.

\section{Exclusion criteria}

People living with HIV were previously infected or currently infected with TB at the time of the research were excluded from the study. This was done to reduce the risk of bias because of personal TB experiences while answering the questions.

\section{Ethical considerations}

An approval to conduct the study was obtained from Lagos state Research and Ethic Committee before the commencement of the study. Informed consent was obtained from each of the respondents 
before they were interviewed. Respondents were asked to give their consents by filling informed consent forms.

\section{Results}

A total of 345 respondents participated in the study. Respondents were all people living with HIV enrolled into care and treatment. Majority of respondents were Females 209 (60.6\%), while males constitutes 136 (39.4\%). Although majority of the respondents lack good knowledge about TB infection. The respondents have fair attitude towards TB infection control. This suggests that the rational attitude of TB patients is because they have been exposed to prevention and care because they are screened for TB during each clinic visit Hence the patients, therefore, understood the benefits the facility care and support screening checklist used at the triage station.

The study found that the mean level of attitude of people living with HIV towards TB infection control is fair (55\% of the respondents with a mean of $2.49(\mathrm{SD}=0.93)$ on a scale of 0 to 4 . These findings suggest a positive attitude towards TB control by some of the respondents. The results may be explained by the fact that the respondents with unknown HIV status were aware of the benefits the facility care and support screening checklist used at the triage station.

The study found that the mean level of perception of people living with HIV towards TB infection control is better in comparison to their knowledge and attitude. These findings suggest a positive perception towards TB control by many of the respondents in the results may be explained by the mandate at the health facility by the health care provider that every presumptive client should wear a mask or tie a piece of handkerchief covering their mouth and nose. Hence it is suggested that health workers do not only mandate the patients to cover their mouth and nose but should also explain the reason behind the action.

Table 1. Showing knowledge categorization

\begin{tabular}{|l|l|l|l|l|l|}
\hline \multicolumn{2}{|c|}{} & $\begin{array}{l}\text { Frequenc } \\
\text { y }\end{array}$ & Percent & $\begin{array}{l}\text { Valid } \\
\text { Percent }\end{array}$ & $\begin{array}{l}\text { Cumulative } \\
\text { Percent }\end{array}$ \\
\hline \multirow{3}{*}{ Valid } & Poor & 222 & 64.3 & 64.3 & 64.3 \\
\cline { 2 - 6 } & Fair & 123 & 35.7 & 35.7 & 100.0 \\
\cline { 2 - 6 } & Total & 345 & 100.0 & 100.0 & \\
\hline
\end{tabular}

Table 2. Showing crosstabs- relationship between knowledge and socio-demographics

\begin{tabular}{|c|c|c|c|c|}
\hline \multicolumn{5}{|c|}{ Crosstab } \\
\hline \multicolumn{5}{|c|}{ Count } \\
\hline & & \multicolumn{2}{|c|}{$\begin{array}{l}\text { knowledge } \\
\text { categorisation }\end{array}$} & \multirow[t]{2}{*}{ Total } \\
\hline & & Poor & Fair & \\
\hline \multirow[t]{2}{*}{ Gender } & Male & 88 & 48 & 136 \\
\hline & Female & 134 & 75 & 209 \\
\hline \multicolumn{2}{|l|}{ Total } & 222 & 123 & 345 \\
\hline
\end{tabular}

Table 3. Showing chi-square tests

\begin{tabular}{|l|l|l|l|l|l|}
\hline & Value & df & $\begin{array}{l}\text { Asymp. Sig. } \\
(2 \text {-sided })\end{array}$ & $\begin{array}{l}\text { Exact Sig. (2- } \\
\text { sided) }\end{array}$ & $\begin{array}{l}\text { Exact Sig. (1- } \\
\text { sided) }\end{array}$ \\
\hline Pearson Chi-Square & $.013^{\mathrm{a}}$ & 1 & .911 & & \\
\hline $\begin{array}{l}\text { Continuity } \\
\text { Correction }\end{array}$ & .000 & 1 & 1.000 & & \\
\hline Likelihood Ratio & .013 & 1 & .911 & & \\
\hline Fisher's Exact Test & & & & 1.000 & .502 \\
\hline $\begin{array}{l}\text { Linear-by-Linear } \\
\text { Association }\end{array}$ & .013 & 1 & .911 & & \\
\hline N of Valid Cases & 345 & & & & \\
\hline
\end{tabular}


DOI: $10.21522 /$ TIJPH.2013.05.04.Art049

ISSN: 2520-3134

a. 0 cells $(0.0 \%)$ have expected count less than 5 . The minimum expected count is 48.49

b. b. Computed only for a $2 \times 2$ table

Table 3.1. Socio-demographic characteristics of respondents $(\mathrm{N}=345)$

\begin{tabular}{|c|c|}
\hline Variables & $\mathbf{N}(\%)$ \\
\hline \multicolumn{2}{|l|}{ Sex } \\
\hline Male & $136(39.4)$ \\
\hline Female & $209(60.6)$ \\
\hline \multicolumn{2}{|l|}{ Age (Years) } \\
\hline $15-24$ & $5(1.4)$ \\
\hline $25-34$ & $196(56.8)$ \\
\hline $35-44$ & $106(30.7)$ \\
\hline $45-54$ & $38(11)$ \\
\hline \multicolumn{2}{|l|}{ Ethnic group } \\
\hline Yoruba & $113(32.8)$ \\
\hline Hausa & $44(12.8)$ \\
\hline Igbo & $188(54.5)$ \\
\hline Employment status & $192(55.7)$ \\
\hline \multicolumn{2}{|l|}{ Employed } \\
\hline Self-employed & $120(34.8)$ \\
\hline Out of work & $9(2.6)$ \\
\hline Student & $24(7.0)$ \\
\hline \multicolumn{2}{|c|}{ Highest level of education } \\
\hline No formal education & $10(2.9)$ \\
\hline Primary education & $24(7)$ \\
\hline Secondary education & $212(61.4)$ \\
\hline Tertiary education & $99(28.7)$ \\
\hline \multicolumn{2}{|l|}{ Marital Status } \\
\hline Married & $152(44.1)$ \\
\hline Divorced & $44(12.8)$ \\
\hline Never Married & $103(29.9)$ \\
\hline Widowed & $15(4.3)$ \\
\hline Separated & $31(9.0)$ \\
\hline \multicolumn{2}{|c|}{ Number of years in HIV Care } \\
\hline$\leq 1$ & $263(76.2)$ \\
\hline $1-2$ & $77(22.3)$ \\
\hline $2-4$ & $5(1.4)$ \\
\hline 5 and Above & $0(0)$ \\
\hline
\end{tabular}

Table 4. Showing knowledge of respondent based on their educational qualification

\begin{tabular}{|l|l|l|l|l|l|l|}
\hline \multicolumn{2}{|l|}{ Educational Background } & \multicolumn{2}{|l|}{ knowledge categorisation } & \multirow{2}{*}{ Total } & & \\
\cline { 3 - 4 } \cline { 6 - 7 } & poor & Fair & & & Poor\% & fair (\%) \\
\hline & $\begin{array}{l}\text { No formal } \\
\text { Education }\end{array}$ & 7 & 3 & 10 & 70 & 30 \\
\hline $\begin{array}{l}\text { Primary } \\
\text { Education }\end{array}$ & 16 & 8 & 24 & 66.66667 & 33.33333 \\
\hline $\begin{array}{l}\text { Secondary } \\
\text { Education }\end{array}$ & 136 & 76 & 212 & 64.15094 & 35.84906 \\
\hline
\end{tabular}




\begin{tabular}{|l|l|l|l|l|l|l|}
\hline & $\begin{array}{l}\text { Tertiary } \\
\text { Education }\end{array}$ & 63 & 36 & 99 & 63.63636 & 36.36364 \\
\hline Total & 222 & 123 & 345 & 64.34783 & 35.65217 \\
\hline
\end{tabular}

Result showed that those with tertiary education had better knowledge of TB infection control while those without formal education had the poorest knowledge about TB infection control.

\section{Discussion}

Level of awareness about TB was quite high with $71.9 \%$ of respondent mentioning they had "heard of an illness called tuberculosis (TB)." But only $29.7 \%$ of respondent knew that TB is not caused by cold and $45.8 \%$ of respondent knew that TB is transmitted "by air when coughing or sneezing." Only $30.4 \%$ know that TB treatment are readily available. The finding showed that only $123(35.7 \%)$ out of 345 had fair Knowledge regarding Tb infection control which is in line with the study by Wang, Fei, Shen, XU in 2008 which stated that only about $16.0 \%$ of the general population were knowledgeable to know that prolonged cough with the duration of 3 weeks or longer is a sign of TB (10). Females had higher overall fair knowledge with 75 (60.9\%) females out of 123 having fair Knowledge of TB infection control while only 48(39\%) males out of 123 had over all fair knowledge of TB infection control.

The study found that the mean level of perception of people living with HIV towards TB infection control is better in comparison to their knowledge and attitude. These findings suggest a positive perception towards TB control by many of the respondents in the results may be explained by the mandate at the health facility by the health care provider that every presumptive client should wear a mask or tie a piece of handkerchief covering their mouth and nose. Hence it is suggested that health workers do not only mandate the patients to cover their mouth and nose but should also explain the reason behind the action.

\section{Conclusion and recommendations}

Findings from this study revealed that despite a relatively fair perception and attitude towards TB infection control by people living with HIV, there was poor knowledge about TB infection prevention and control. Results also showed majority of the respondent were aware of TB but still lack adequate knowledge about TB. Everyone living with HIV; especially those that are not infected with TB and even those infected with $\mathrm{TB}$ should be given adequate information to improve their knowledge regarding major causative agent of the TB, principal probable symptoms and sign of the TB infection, TB/HIV co-infection; its transmission and prevention which includes various social dimensions of TB and its related stigma. Health education especially for people living with HIV regarding TB infection. There is need for the health workers at the triage station carrying out the TB screening to give adequate information to this group of people which will eventually lead to behavioral change.

\section{References}

[1].Chawla. S, Sahoo. S, Jain. R, Khanna. P, Mehta. P, and Singh. I, (2014). Human vaccine and immunotherapeutic https://www.ncbi.nlm.nih.gov/pmc/articles/PMC4181026.

[2].Colombani. P, Banatvala. N, Zaleskis. R, Maher. D. (2004). European Framework to Decrease the Burden of TB/HIV. European Respiratory Journal, 24(3):493-501.

[3].Davaalkham D., PhD, Naranzul D., Tsolmon B., Kh.Ser-Od, Batzorig B., Davaa G., PhD, Lecturer, DEB, SPH, HSUM N. Khuderchuluun, MPH, D.Gantuya, O. Nandin-Erdene, G. Tsendmaa,. Knowledge, Attitudes and Practices on Tuberculosis among General Population. The nationwide study report. Ulaanbaatar. 2012.

[4].Datiko, D.G., Yassin, M.A., Chekol, L.T., Kabeto, L.E. \& Lindtjorn, B. (2008). The Rate of TBHIV Co infection Depends on the Prevalence of HIV Infection in a Community.

[5].Jianming Wang, Yang Fei, Hongbing Shen, and Biao Xu. Gender difference in knowledge of tuberculosis and associated health-care seeking behaviors: a cross-sectional study in a rural area of China. BMC Public Health. 2008; 8: 354.Published online 2008 Oct 8. doi: 10.1186/1471-2458-8-354 PMCID: PMC2577657.

[6].Kigozi, N.G., Heunis, J.C., Chikobvu, P., Van den Berg, H., Van Rensburg, H.C. \& Wouters, E.(2010). Predictors of Uptake of Human Immunideficiency Virus Testing by Tuberculosis Patients in Free State Province, South Africa. The International Journal of Tuberculosis and Lung Disease, 14(4):399-405. 
DOI: $10.21522 / \mathrm{TIJPH} .2013 .05 .04$.Art049

ISSN: $2520-3134$

[7].Muktar, H.A. \& Hamisu, S.M. (2003). Tuberculosis and HIV Disease: Two Decades of a Dual Epidemic. Biomed Experts, 115(19-20): 685-97.

[8].Munseri, P.J., Talbot, E.A., Mtei, L. \& Von Reyn, C.F. (2008). Completion of Isoniazide Preventive Therapy among HIV-Infected Patients in Tanzania. International Journal of Tuberculosis and Lung Disease, 12(9):10371041.

[9].Sharma, S.K., Mohan, A. \& Kadhiravan, T. (2005). HIV-TB Co-infection: Epidemiology, Diagnosis and Management. Indian Journal of Medical Research, 121:550-567.The Chambers Dictionary. New Delhi: Allied Chambers India Ltd. 1998. p. 352. ISBN 978-81-86062-25-8.

[10]. WHO factsheet, 2016 [Online], Available: http://www.who.int/mediacentre/factsheets/fs360/en/ [Accessed 04//04/17: 20:05PM]. 